\title{
Influence of Weed Management Practices on Weed Control Efficiency, Yield and Economics in Sweet Corn (Zea mays L. saccharata)
}

\author{
S.S.S. Bhardwaj, G.C. Mishra and S.K. Lenka
}

M.S. Swaminathan School of Agriculture, Centurion University of Technology and Management, Paralakhemundi, Odisha, India *Corresponding author: gcmishra@cutm.ac.in (ORCID ID: 0000-0003-0803-7169)

Paper No. 813

Received: 08-10-2019

Revised: 14-01-2020

Accepted: 23-02-2020

\begin{abstract}
The field experiment was conducted in sandy loam soil at Research Farm, M.S. Swaminathan School of Agriculture, Centurion University of Technology and Management, Bagusala village, Paralakhemundi, Odisha, India during summer season of 2018. The experiment was laid out in randomized complete block design with three replications and eight treatments. The herbicidal treatmentrs of pre emergence (PE) application of either pendimethalin@ $0.75 \mathrm{~kg} / \mathrm{ha}$, oxyfluorfen @ $50 \mathrm{~g} / \mathrm{ha}$ and metribuzin @ $0.3 \mathrm{~kg} / \mathrm{ha}$ at 1 day after sowing (DAS) or the same herbicides supplimented with straw mulching (SM) @ $6 \mathrm{t} / \mathrm{ha}$ at 30 DAS were compared with intercultivation twice at 20 and 40 DAS and unweeded control.

Experimental results revealed that weed mangement treatments significantly influenced the yield attributes and yield of sweet corn along with improvement in weed control efficiency. Pre emergence application of either metribuzin @ $0.30 \mathrm{~kg} / \mathrm{ha}$ or pendimethalin @ $0.75 \mathrm{~kg} / \mathrm{ha}$ at 1 DAS in combination with SM@6.0 t/ha at 30 DAS remarkbly enhanced the yield attributes such as number of cobs/plant, cob length, cob girth and cob weight. The green cob (11.78 t/ha) and forage (14.55 t/ha) yield were the highest with metribuzin @ $0.30 \mathrm{~kg} / \mathrm{ha}$ as PE at 1 DAS + SM @ $6 \mathrm{t} / \mathrm{ha}$ at 30 DAS. It was followed by pendimethalin @ $0.75 \mathrm{~kg} / \mathrm{ha}$ as PE at $1 \mathrm{DAS}+\mathrm{SM} @ 6 \mathrm{t} / \mathrm{ha}$ at $30 \mathrm{DAS}$ producing the green cob and forage yield of 11.21 and $14.22 \mathrm{t} /$ ha, respectively. The reduction in yield was to the tune of $35.10 \%$ due to uninterrupted growth of weeds. The maximum gross return ( $₹ 250150 /$ ha), net return ( $₹ 181635 / \mathrm{ha}$ ) and B:C ratio (2.65) were obtained with PE application of metribuzin @ $0.30 \mathrm{~kg} / \mathrm{ha}$ at 1 DAS + SM @ $6 \mathrm{t} / \mathrm{ha}$ at 30 DAS. It was followed by pendimethalin @ $0.75 \mathrm{~kg} / \mathrm{ha}$ as PE at 1 DAS + SM @ $6 \mathrm{t} / \mathrm{ha}$ at 30 DAS registering the gross and net return of ₹ 238420/ ha and ₹ 169605 /ha, respectively.

Highlights

( Pre emergence application of metribuzin @ $0.3 \mathrm{~kg} / \mathrm{ha}$ at 1 day after sowing supplimented with straw mulching @ $6 \mathrm{t} / \mathrm{ha}$ at 30 days after sowing was observed as an efficient and economical method of weed management in sweet corn.
\end{abstract}

Keywords: Weed management, pre emergence application, pendimethalin, oxyfluorfen, metribuzin, straw mulching, weed control efficiency, yield, economics and sweet corn

Sweet corn is successfully grown for vegetable purpose in countries like Canada, United States of America and Sri Lanka. In India, it's cultivation is popular in Haryana, Maharashtra, Meghalaya, Karnataka, and Andhra Pradesh. Now a days, the cultivation of sweet corn is extended to other states to meet the local need of urban population. Among the several constraints in sweet corn cultivation, the most critical for low yield is the weed competetion for nutrients, water, sunlight and space. In the summer maize, weed emerges most often after the first irrigation. However, wider row spacing, slow initial growth and liberal use of irrigation and fertilizers lead to more growth of weeds. The heavy weed infestation resulted in huge losses ranging from 60 to $83 \%$ in maize grown 
in a wider spacing (Kumar et al. 2015 and Ehsas et al. 2016). The choice of weed control methods largely depends on it's effectiveness and economics. Manual weeding is very tedious, time taking and costly. The chemical method of weed control as pre-emergence application of herbicides is the cost effective control of the weeds during initial period of crop development stage. The pre-emergence use of pendimethalin (Verma et al. 2015; Dobariya et al. 2015; and Barad et al. 2016), metribuzin (Shaba et al. 2015 and Roshdy 2017) and oxyfluorfen (Nadiger et al. 2013 and Madhavi et al. 2013) has been tested as a method of weed control in maize by many weed scientists.

But the efficacy of herbicides is reduced by various climatic and edaphic factors. Therefore, the only alternative is required to explore the integration of pre emergence application of herbicides with cultural method to give priority for weed management in Indian agriculture scenario. The farmers are used to burn the crop residues after harvest of rice mechanically by combine harvester. It pollutes the atmosphere and causes human health hazards. Under such situation, straw mulching is the effective method to manage the weeds successfully and also prevents atmospheric pollution and increases the soil fertility due to in situ decomposition of paddy straw. Several workers reported the favourable effect of mulching in reducing the weed completion to serve as an effective way of weed management (Olabode and Sangodele 2015 and Ehsas et al. 2016). Keeping the above facts in view, the present investigation entitled "Integrated weed management in sweet corn (Zea mays L. saccharata)" was carried out to devise an acceptable, effective and economical method of weed management.

\section{MATERIALS AND METHODS}

A field experiment was carried out in sandy loam soil at Research Farm, Bagusala, M.S. Swaminathan School of Agriculture, Centurion University of Technology and Management, Paralakhemundi Odisha during summer 2018. The of experimental soil was slighly acidic ( $\mathrm{pH}$ of 6.8 ) with low in available $\mathrm{N}(158.83 \mathrm{~kg} / \mathrm{ha})$ and $\mathrm{P}_{2} \mathrm{O}_{5}(10.82 \mathrm{~kg} / \mathrm{ha})$ and medium in available $\mathrm{K}_{2} \mathrm{O}(147.67 \mathrm{~kg} / \mathrm{ha})$. The randomized complete block design was adopted with three replications and eight treatments in plot size of $4.8 \mathrm{~m} \times 4.20 \mathrm{~m}$. The details of weed management treatments were pre emergence application of pendimethalin @ $0.75 \mathrm{~kg} / \mathrm{ha}$ at 1 DAS, pre emergence application of oxyfluorfen @ $50 \mathrm{~g} /$ ha at $1 \mathrm{DAS}$, pre emergence application of metribuzin @ $0.3 \mathrm{~kg} / \mathrm{ha}$ at $1 \mathrm{DAS}$, pre emergence application of pendimethalin @ $0.75 \mathrm{~kg} / \mathrm{ha}$ at 1 DAS + strawmulching ( SM ) @ 6 t/ha at 30 DAS, pre emergence application of oxyfluorfen @ $50 \mathrm{~g} / \mathrm{ha}$ at $1 \mathrm{DAS}+\mathrm{SM} @ 6 \mathrm{t} / \mathrm{ha}$ at $30 \mathrm{DAS}$, pre emergence application of metribuzin@0.3 kg/ha+SM@6 t/ ha at 30DAS, intercultivation twice at 20 and 40 DAS and unweeded control (Weedy check). The sweet corn hybrid sugar-75 was sown in line at the depyh of $5 \mathrm{~cm}$ on 28 th January, 2018 with spacing of $60 \mathrm{~cm}$ from row to row and $25 \mathrm{~cm}$ from seed to seed. The recommended dose of $120-60-60 \mathrm{~kg}$ of $\mathrm{N}, \mathrm{P}_{2} \mathrm{O}_{5}$ and $\mathrm{K}_{2} \mathrm{O}$ was used in sweet corn crop. At sowing, full dose of $\mathrm{P}_{2} \mathrm{O}_{5}$, half of $\mathrm{K}_{2} \mathrm{O}$ and half nitrogen were applied as basal. Rest amount of $\mathrm{N}$ and $\mathrm{K}_{2} \mathrm{O}$ were topdressed at knee high stage at 30 days after sowing (DAS). The pre emergence spray of herbicides as per the ttreatments specification was done with knapsack hand operated sprayer using spray volume of 5001 /ha at one day after sowing. The weed dry weight was taken from all treatments from as area of $50 \mathrm{~cm} \times 50 \mathrm{~cm}$ quadrant at 45 and 60 DAS. The plant protection measure was followed according to recommeded practices of th region. The green cob was harvested two times by pluking at soft dough stage on $13^{\text {th }}$ and $20^{\text {th }}$ April, 2018. The crop was harvested as green fodder purpose after final plucking. The biometric observation on yield attributes and yield were recorded at plucking of cob along with green forage yield after harvesting the whole plant from each plot.

\section{RESULTS AND DISCUSSION}

\section{Major weed floras in experimental site}

The experimental field was infested with the major weed species like Dactyloctenium aegyptium L. Digitaria sanguinalis L. and Sporobolus diander L., Echinochloa colunum L. and Cynodon dactylon L., amongst grasses, Cyperus rotundus L. as a sedge and Phyllanthus niruri L., Oldenlandia corymbosa L. Cleome gynandra L., Physalis minima L., Euphorbia hirta L., Heliotropium indicum L. and Chenopodium album L. under broad leaved weeds. 


\section{Weed control efficiency}

The weed control efficiency (WCE) recoded at at 45 days after sowing (DAS) was improved with pre emergence application of all herbicides supplimented with straw mulching at 45 days after sowing (Table 1). Application of pendimethalin @ $0.75 \mathrm{~kg} / \mathrm{ha}$, metribuzin @ $0.3 \mathrm{~kg} / \mathrm{ha}$ and oxyfluorfen @ $50 \mathrm{~g} / \mathrm{ha}$ applied as PE at 1 DAS + straw mulching @ $6 \mathrm{t} / \mathrm{h}$ a recorded more or less equal values of WCE ranging from 98.57 to $98.27 \%$. It was followed by inter cultivation at 20 and 40 DAS (95.14\%). The weed control efficiency obtained with all pre emergence application of herbicides at 1 DAS and weed check was lower than the above mentioned treatments during 45 DAS. Improvement in WCE was achieved due to efficient method of weed management resulted in reduced biomass production of weeds at initial crop growth stage with pre emergence application of herbicides and effective weed control by mulching at later stage provided weed free condition. Similar favourable effect in pre emergence application of metribuzin (Shaba et al. 2015) and pre emergence application of Pendimethalin or oxyfluorfen + intercultivation (Madhavi et al. 2013) and mulching (Olabode and Sangodele 2015; Abdullah et al. 2016 and Ehsas et al. 2016) in reducing the weed dry matter accumulation and increasing the weed control efficiency was noticed earlier by different research workers.

\section{Yield attributes of sweet corn}

The data on yield parameters with respect to cobs/ plant, cob length, cob girth and cob weight are presented in (Table 1). It indicated that the weed management treatments exerted significant effect on yield components of sweet corn. The maximum number of cobs/plant was recorded in pendimethalin @ $0.75 \mathrm{~kg} / \mathrm{ha}$ as PE at 1 DAS + straw mulching @ $6 \mathrm{t} /$ ha ( 1.27 ) closely followed by metribuzin @ $0.3 \mathrm{~kg} / \mathrm{ha}$ as PE at 1 DAS + straw mulching @ $6 \mathrm{t} / \mathrm{ha} \mathrm{(1.23)} \mathrm{and}$ pendimethalin@ $0.75 \mathrm{~kg} / \mathrm{ha}$ as PE at 1 DAS which were at par. The least number of cobs /plant was recorded in unweeded check (1.0). Length of cob was maximum with metribuzin @ $0.3 \mathrm{~kg} / \mathrm{ha}$ as PE at 1 DAS + straw mulching @ $6 \mathrm{t} / \mathrm{ha}(22.14 \mathrm{~cm})$ closely followed by pendimethalin @ $0.75 \mathrm{~kg} / \mathrm{h}$ a as PE at 1 DAS + straw mulching @ $6 \mathrm{t} / \mathrm{ha}(22.13 \mathrm{~cm})$. The cob length did not vary significantly among all other weed management treatments except in unweeded control. Metribuzin @ $0.3 \mathrm{~kg} / \mathrm{ha}$ as PE at 1 DAS + straw mulching @ $6 \mathrm{t} / \mathrm{ha}$ gave the highest cob girth $(19.07 \mathrm{~cm})$ followed by pendimethalin @ $0.75 \mathrm{~kg} /$ ha as PE at 1 DAS + straw mulching @ $6 \mathrm{t} /$ ha $(18.25$ $\mathrm{cm})$ which remained at par with other treatments except pre emergence application of pendimethalin @ $0.75 \mathrm{~kg} / \mathrm{ha}$ as PE at 1 DAS and oxyfluorfen @ 50 $\mathrm{g} / \mathrm{ha}$ as PE at 1 DAS and unweeded control. The highest cob weight was obtained with metribuzin @ $0.3 \mathrm{~kg} / \mathrm{ha}$ as PE at 1 DAS + straw mulching @

Table 1: Weed control efficiency (WCE) and yield components of sweet corn as influenced by weed management treatments

\begin{tabular}{|c|c|c|c|c|c|}
\hline Treatments & $\begin{array}{l}\text { WCE at } 45 \\
\text { DAS }(\%)\end{array}$ & $\begin{array}{l}\text { Cobs/ } \\
\text { plant }\end{array}$ & $\begin{array}{l}\text { Cob length } \\
(\mathrm{cm})\end{array}$ & $\begin{array}{l}\text { Cob girth } \\
(\mathrm{cm})\end{array}$ & $\begin{array}{l}\text { Cob weight } \\
\text { (g) }\end{array}$ \\
\hline Pendimethalin @ $0.75 \mathrm{~kg} / \mathrm{ha}$ as PE at1DAS & 57.80 & 1.20 & 21.8 & 17.60 & 296 \\
\hline Oxyfluorfen @ $50 \mathrm{~g} / \mathrm{ha}$ as PE at 1 DAS & 53.25 & 1.07 & 20.57 & 17.53 & 289 \\
\hline Metribuzin @ $0.3 \mathrm{~kg} / \mathrm{ha}$ as PE at 1 DAS & 60.69 & 1.13 & 21.40 & 17.77 & 299 \\
\hline $\begin{array}{l}\text { Pendimethalin @ } 0.75 \mathrm{~kg} / \mathrm{ha} \text { as PE at } 1 \mathrm{DAS}+\text { straw } \\
\text { mulching @ } 6 \mathrm{t} / \mathrm{ha}\end{array}$ & 98.57 & 1.27 & 22.13 & 18.25 & 305 \\
\hline $\begin{array}{l}\text { Oxyfluorfen @ } 50 \mathrm{~g} / \mathrm{ha} \text { as PE at } 1 \mathrm{DAS}+\text { straw } \\
\text { mulching @ } 6 \mathrm{t} / \mathrm{ha}\end{array}$ & 98.27 & 1.20 & 21.80 & 18.13 & 301 \\
\hline $\begin{array}{l}\text { Metribuzin @ } 0.3 \mathrm{~kg} / \mathrm{ha} \text { as PE at } 1 \text { DAS + straw } \\
\text { mulching @ } 6 \mathrm{t} / \mathrm{ha}\end{array}$ & 98.45 & 1.23 & 22.14 & 19.07 & 308 \\
\hline Inter cultivation at 20 and 40 DAS & 95.14 & 1.13 & 20.67 & 18.13 & 292 \\
\hline Un weeded control & - & 1.00 & 18.00 & 16.55 & 246 \\
\hline S. Em. $( \pm)$ & - & 0.04 & 0.71 & 0.43 & 9 \\
\hline $\mathrm{CD}(\mathrm{P}=0.05)$ & - & 0.12 & 2.16 & 1.30 & 28 \\
\hline
\end{tabular}


6 t/ha (308 g) closely followed by pendimethalin @ $0.75 \mathrm{~kg} / \mathrm{ha}$ as PE at 1 DAS + straw mulching @ $6 \mathrm{t} / \mathrm{ha}(305 \mathrm{~g})$. The cob weight recorded in all the weed management treatments except weedy check did not differ significantly among themselves with regard to cob weight. The least competition offered by weeds provided favourable condition for better availability and utilization of nutrients and moisture at crucial growth stages under those treatments resulted in enhanced the crop growth and greater leaf area for efficient photosynthetic activity as well as maximum translocation of photosynthates from source to sink ultimately resulted in enhancement of all yield attributes. Similar favourable effect of pre emergence application of herbicides like pendimethalin (Dobariya et al. 2015 and Barad et al. 2016), metribuzin (Roshdy et al. 2017) and oxyfluorfen (Nadiger et al. 2013) and in increasing the yield attributes on maize is corroborated with the findings of earlier weed scientists. Straw mulching successfully restricted weed emergence by curtailing solar radiation thus provided favourable growth factor for enhancing yield attributes. It is in pipe line with the works of Abdullah et al. (2016).

\section{Green cob and forage yield and weed index}

The data on green cob and forage yield and weed index $(\%)$ depicted in Table 2 indicated that green cob and forage yield were significantly affected by weed management treatments. The highest green cob yield was recorded with metribuzin@ 0.3 $\mathrm{kg} / \mathrm{ha}$ as PE at 1 DAS + straw mulching @ $6 \mathrm{t} / \mathrm{ha}$ (11.78 t/ha) closely followed by pendimethalin @ $0.75 \mathrm{~kg} / \mathrm{ha}$ as PE at 1 DAS + straw mulching @ $6 \mathrm{t} /$ ha $(11.21 \mathrm{t} / \mathrm{ha})$. This performance was on par with remaining weed management treatments except unweeded control. Application of metribuzin @ $0.3 \mathrm{~kg} / \mathrm{ha}$ as PE at $1 \mathrm{DAS}+$ straw mulching @ $6 \mathrm{t} /$ ha recorded maximum green forage yield (14.55 $\mathrm{t} /$ ha) being at par with pendimethalin @ $1 \mathrm{~kg} / \mathrm{ha}$ as PE at 1 DAS + straw mulching @ $6 \mathrm{t} / \mathrm{ha}(14.22 \mathrm{t} / \mathrm{ha})$. Those treatments also remained at par with all the weed management treatments except oxyfluorfen @ 50.g /ha as PE at 1DAS and unweeded control. The increased yield in those treatments could be attributed due to improved yield components such as higher of cob plant ${ }^{-1}$, cob length, cob girth and cob weight. Thus, resultant effect on improvement in total dry matter accumulation in sweet corn as

Table 2: Effect of weed management treatments on green cob yield, green forage yield, weed index and economics of sweet corn

\begin{tabular}{|c|c|c|c|c|c|c|}
\hline Treatments & $\begin{array}{l}\text { Green cob } \\
\text { yield (t/ha) }\end{array}$ & $\begin{array}{l}\text { Green forage } \\
\text { yield (t/ha) }\end{array}$ & $\begin{array}{l}\text { Weed } \\
\text { index (\%) }\end{array}$ & $\begin{array}{l}\text { Cost of } \\
\text { cultivation }(₹ / \mathrm{ha}\end{array}$ & $\begin{array}{l}\text { Net profit } \\
\text { (₹/ha) }\end{array}$ & $\begin{array}{l}\text { Benefit: } \\
\text { cost ratio }\end{array}$ \\
\hline $\begin{array}{l}\text { Pendimethalin @ } 0.75 \mathrm{~kg} / \mathrm{ha} \text { as PE at } \\
1 \text { DAS }\end{array}$ & 10.4 & 12.98 & 11.77 & 65815 & 155165 & 2.36 \\
\hline $\begin{array}{l}\text { Oxyfluorfen @ } 50 \mathrm{~g} / \mathrm{ha} \text { as PE at } 1 \\
\text { DAS }\end{array}$ & 10.15 & 12.29 & 13.86 & 64696 & 150594 & 2.33 \\
\hline $\begin{array}{l}\text { Metribuzin @ } 0.3 \mathrm{~kg} / \mathrm{ha} \text { as PE at } 1 \\
\text { DAS }\end{array}$ & 10.85 & 12.70 & 7.92 & 65515 & 164185 & 2.51 \\
\hline $\begin{array}{l}\text { Pendimethalin @ } 0.75 \mathrm{~kg} / \mathrm{ha} \text { as PE at } \\
1 \text { DAS + straw mulching @ } 6 \mathrm{t} / \mathrm{ha}\end{array}$ & 11.21 & 14.22 & 4.91 & 68815 & 169605 & 2.46 \\
\hline $\begin{array}{l}\text { Oxyfluorfen @ } 50 \mathrm{~g} / \mathrm{ha} \text { as PE at } 1 \text { DAS } \\
\text { + straw mulching @ } 6 \mathrm{t} / \mathrm{ha}\end{array}$ & 11.11 & 13.42 & 5.71 & 67696 & 167924 & 2.48 \\
\hline $\begin{array}{l}\text { Metribuzin @ } 0.3 \mathrm{~kg} / \mathrm{ha} \text { as PE at } 1 \\
\text { DAS + straw mulching @ } 6 \mathrm{t} / \mathrm{ha}\end{array}$ & 11.78 & 14.55 & - & 68515 & 181635 & 2.65 \\
\hline Inter cultivation at 20 and $40 \mathrm{DAS}$ & 10.99 & 13.24 & 6.70 & 83190 & 149850 & 1.80 \\
\hline Un weeded control & 7.65 & 9.07 & 35.10 & 63190 & 98880 & 1.56 \\
\hline S. Em. $( \pm)$ & 0.54 & 0.72 & - & - & - & - \\
\hline $\mathrm{CD}(\mathrm{P}=0.05)$ & 1.63 & 2.19 & - & - & - & - \\
\hline CV $(\%)$ & 8.84 & 9.75 & - & - & - & - \\
\hline
\end{tabular}

Seeling price of produce - Green cob $=₹ 20000 / t$ and green forage $=₹ 1000 / t$ 
a result of lower weed competition was favourable in proper utilization of growth factors there by reflected green cob and forage yield. This result is in accordance with the various research workers while working with pre mergence application of pendimethalin (Madhavi et al. 2013; Verma et al. 2015 and Barad et al. 2016), metribuzin (Roshdy et al. 2017) and oxyfluorfen (Nadiger et al. 2013 and Hatti et al. 2014) and with straw mulching (Abdullah et al. 2016).

The efficient weed index was observed in pendimethalin@ $0.75 \mathrm{~kg} / \mathrm{ha}$ as PE at 1 DAS + straw mulching@ 6 t/ha (4.91\%) closely followed by oxyfluorfen @50 g/ha as PE at 1 DAS + straw mulching@6 t/ha (5.71\%) where in metribuzin @ 0.3 $\mathrm{kg} \mathrm{ha}^{-1}$ as pre emergence 1 DAS with straw mulching @ $6 \mathrm{t} \mathrm{ha}^{-1}$ was taken as best treatments (Table 2). The uninterrupted growth of weeds reduced the green cob yield by $35.10 \%$ compared with the best treatment. Dobariya et al. (2015) reported the reduction in yield by $29.86 \%$ due to uninterrupted growth of weeds in sweet corn.

\section{Economics of cultivation}

The economics of cultivation calculated basing upon prevailing market price revealed that the cost of cultivation was maximum in inter cultivation at 20 and 40 DAS (₹ $83190 /$ ha) and the lowest (₹ 63190/ ha) in unweeded check plot (Table 2). Application of metribuzin@ $0.3 \mathrm{~kg} / \mathrm{ha}$ as PE at 1 DAS + straw mulching@6 t/ha registered the highest net return (₹ 181635/ ha) followed by pendimethalin @ 0.75 $\mathrm{kg} / \mathrm{ha}$ as PE at 1 DAS + straw mulching @ $6 \mathrm{t} / \mathrm{ha} \mathrm{(₹}$ $169605 /$ ha). The cost benefit ratio was maximum in metribuzin@ $0.3 \mathrm{~kg} / \mathrm{ha}$ as PE at 1 DAS + straw mulching @ $6 \mathrm{t} /$ ha (2.65) and the same metribuzin as pre emergence spray recorded the next value of 2.51. This is because of higher economic yield, net return and lower cost of cultivation. The increase in benefit under these treatments might be due to enhancement in green cob and forage production leading to increased monetary return with comparatively acceptable cost of cultivation. These findings are in close vicinity with the views of Hawaldar and Agasimani (2012) and Arvadiya et al. (2012).

\section{CONCLUSION}

The pre emergence application of metribuzin @ 0.3 kg/ha at 1 DAS + straw mulching @ 6 t/ha enhanced the yield attributes like cobs/plant, cob length, cob girth and green cob weight and gree green cob (11.78 t/ha) and forage (11.21 t/ha) yield of sweet corn along with net return return (₹ 181635/ ha) and benefit cost ratio (2.65).

\section{REFERENCES}

Abdullah, S., Ghosh, G. and Dawson, J. 2016. Effect of different weed control methods on growth and yield of maize (Zea mays L.) under rainfed condition in Allahabad. Journal of Agriculture and Veterinary Science, 9(4): 44-47.

Arvadiya, L.K., Raj, V.C., Patel, T.U. and Arvadiya, M.K. 2012. Influence of plant population and weed management on weed flora and productivity of sweet corn (Zea mays). Indian Journal of Agronomy, 57(2): 162-167.

Barad, B., Mathukia, R.K., Gohil, B.S. and Chhodavadia, S.K. 2016. Integrated weed management in rabi pop corn (Zea mays variety everta). Journal of Crop and Weed, 12(1): 150-153.

Dobariya, V.K., Mathukia, R.K, Gohil, B.S. and Ashish Shivran. 2015. Integrated weed management in rabi sweet corn (Zea mays var. saccharata). Journal of Eco-friendly Agriculture, 10(1): 70-83.

Ehsas, J., Desai L.J., Ahir, N.B and Joshi, J.R. 2016. Effect of integrated weed management on growth, yield and yield attributes and weed parameters on summer maize (Zea mays L.) under Southern Gujarat condition. International Journal of Science, Environment and Technology, 5(4): 20502056.

Hatti, V., Sanjay, M.T., Prasad, T.V.R., Murthy, K.N.K., Kumbar, B. and Shruthi, M.K. 2014. Effect of new herbicide molecules on yield, soil microbial biomass and their phytotoxicity on maize (Zea mays L.) under irrigated conditions. The Bioscan., 9(3): 1127-1130.

Hawaldar, S. and Agasimani, C.A. 2012. Effect of herbicides on weed control and productivity of maize (Zea mays L.). Karnataka Jounnal of Agricultural Science, 25(1): 137- 139.

Madhavi, M., Ramprakash, T., Srinivas, A. and Yakadri, M. 2013. Integrated weed management in maize (Zea mays L.) for supporting food security in Andhra Pradesh, India. The role of weed science in supporting food security by 2020. Proceedings of the $24^{\text {th }}$ Asian-Pacific Weed Science Society Conference, Bandung, Indonesia, October 22-25, 2013.

Nadiger, S., Ramesh Babu and Aravinda Kumar, B.N. 2013. Bio-efficacy of pre-emergence herbicides on weed management in maize. Karnataka Journal of Agricultural Science, 26(1): (17-19).

Olabode, O.S. and Sangodele, A.O. 2015. Effect of weed control methods on performance of sweet corn (Zea mays L. saccharata) in Ogbomoso south west Nigeria. Journal of Global Biosciences, 4(10): 1145-1150.

Roshdy M.H., Tagoura, I. and Mosaad, S.M. 2017. Effect of the foliar enrichment and herbicides on maize and associated 




weeds irrigated with drainage water. Annals of Agricultural Sciences, 62: 183-192.

Shaba, S.A., Yehia, Z.R., Safina, S.A. and Abo El-Hassan, R. G. 2015. Effect of maize herbicides on weeds and yield and residual effect on some following crops (Wheat and broad bean). American-Eurasian Journal of Agricultural and Environmental Science, 15(6): 1004-1011.
Verma, S., Verma D.K., S.P. Giri., Singh, K., Singh, R.B. and Pandey, A. 2015. Response of chemical weed management in maize and cowpea intercropping system grown for quality fodder in Eastern Uttar Pradesh. International Journal of Forestry and Crop Improvement, 6(2): 105-109. 